\title{
APLIKASI KORELASI PEARSON DALAM MEMBANGUN MODEL TREE-AUGMENTED NETWORK (TAN) (Studi Kasus Pengenalan Karakter Tulisan Tangan)
}

\author{
Irwan Budi Santoso \\ Jurusan Teknik Informatika, Sains dan Teknologi \\ Universitas Islam Negeri (UIN) Maulana Malik Ibrahim Malang \\ irwan.budi331177@gmail.com
}

\begin{abstract}
Abstrak- Langkah pertama dalam membangun model pengenalan Tree-Augmented Network (TAN) dengan mengukur besarnya hubungan diantara pasangan fitur objek. Salah satu metode yang dapat digunakan mengukur besarnya keeratan hubungan secara linier diantara pasangan fitur adalah Korelasi Pearson. Aplikasi Korelasi Pearson dalam membangun model Tree-Augmented Network (TAN) dalam penelitian ini, akan diujicobakan pada kasus membangun model pengenalan karakter tulisan tangan. Data fitur karakter tulisan tangan untuk kasus ini, diasumsikan mengikuti distribusi gaussian karena estimasi parameter model pengenalannya menggunakan estimator Maximum Likelihood (ML). Hasil eksperimen dengan menggunakan data training yang terdiri dari 5 jenis karakter tulisan tangan, menunjukkan untuk dimensi fitur karakter tulisan tangan 10x30 (30 fitur), akurasi sistem Korelasi Pearson dalam membangun model TAN untuk mengenali karakter tulisan tangan sebesar $88 \%$.
\end{abstract}

Kata Kunci : Korelasi Pearson, Tree-Augmented Network, Karakter Tulisan Tangan, Maximum Likelihood

\section{Pendahuluan}

Salah satu tujuan utama dalam pengembangan metode pengenalan adalah untuk mendapatkan atau meningkatkan akurasi dalam pengenalan. Akurasi suatu metode dalam melakukan pengenalan sangat dipengaruhi oleh seberapa baik model yang dihasilkan metode tersebut dan seberapa baik estimator yang digunakan. Tree-Augmented Network (TAN) adalah salah satu model pengenalan yang secara konsep dibangun dengan memperhatikan hubungan atau dependensi diantara pasangan fitur-fitur objek (Irwan, 2012) dan Maximum Likelihood (ML) adalah salah satu estimator model yang sering digunakan.

Secara konsep keberhasilan dalam meningkatkan akurasi sistem atau pengenalan suatu objek tergantung dari dua hal yaitu metode yang digunakan dalam membangun model pengenalan serta estimator model yang digunakan. Dalam penelitian ini, akan dicoba membahas bagaimana aplikasi motode Korelasi Pearson dalam membangun model TAN.

Model Tree-Augmented Network (TAN) adalah model pengenalan atau klasifikasi yang secara teori dibangun dengan memperhatikan hubungan atau dependensi diantara pasangan fitur objek, sehingga salah satu tahapan penting dalam membangun model pengenalan ini adalah dengan mengukur besarnya hubungan diantara pasangan fitur objek. Pada penelitian ini, akan diaplikasikan metode Korelasi Pearson untuk mengukur keeratan hubungan secara linier diantara pasangan fitur objek sebagai tahapan dalam membangun model TAN serta seberapa besar tingkat akuasi sistem yang dihasilkannya.

\section{Korelasi Pearson}

Korelasi Pearson digunakan untuk mengetahui tingkat atau keeratan hubungan secara linier antara dua variabel 
atau dua fitur objek. Selanjutnya besarnya hubungan ini ditunjukkan dengan koefisien korelasi yang disimbolkan dengan $\rho$ untuk populasi dan $\mathrm{r}$ untuk sampel (DeCoursey, 2003). Bila diketahui fitur $X_{i}=\left\{x_{i 1}, x_{i 2}, \ldots\right.$, $\left.x_{i N}\right\}$ dan fitur $X_{j}=\left\{x_{j 1}, x_{j 2}, \ldots, x_{j N}\right\}$ maka koefisien korelasi dirumuskan sebagai berikut:

$$
\rho\left(X_{i}, X_{j}\right)=\frac{\sigma_{i j}}{\sqrt{\sigma_{i}^{2} \sigma_{j}^{2}}}
$$

dengan nilai $\sigma_{i}^{2}, \sigma_{j}^{2}$ dan $\sigma_{i j}$ merupakan elemen-elemen dari matrik kovarian dari $X_{i}$ dan $X_{j}$ yang ditulis sebagai berikut:

$$
\sum_{i j}=\left[\begin{array}{ll}
\sigma_{i}^{2} & \sigma_{i j} \\
\sigma_{j i} & \sigma_{j}^{2}
\end{array}\right]
$$

Koefisien korelasi yang digunakan untuk mengukur keeratan diantara pasangan fitur objek ini, untuk selanjutnya sebagai bobot pada egde dari sebuah graph.

\section{Tree-Augmented Network (TAN)}

Tree-Augmented Network (TAN) sangat berkaitan dengan naïve Bayes klasifier, karena Tree-Augmented Network adalah hasil pengembangan dari naïve Bayes. Pada nä̈ve Bayes klasifier, diasumsikan bahwa diantara fitur objek bersifat independen. Adanya asumsi independen inilah yang menyebabkan naïve Bayes klasifier tidak realistis untuk diterapkan karena pada faktanya hampir setiap fitur memiliki hubungan atau bersifat dependen terhadap fitur yang lainnya. Sedangkan pada Tree-Augmented Network (TAN) secara konsep dibangun dengan memperhatikan hubungan atau dependensi diantara pasangan fitur-fitur objek. Dalam prakteknya untuk membagun TreeAugmented Network (TAN) dilakukan dengan menemukan Bayesian network yang baik dengan varibel kelas sebagai root-nya serta diperbolehkannya saling mempengaruhi diatara fitur atau variabel (Friedman,1997).
Jika diketahui $U=\left\{X_{1}, \ldots, X n\right\}$ adalah sekumpulan data training, selanjutnya bayesian network dianggap sebagai Directed Acyclic Graph (G) dan merupakan join distribusi probabilitas $U$. Bila diketahui parameter network adalah $\Theta$ maka bayesian network dapat ditulis $B=\langle G, \Theta\rangle$, dan dalam join distribusi probabilitas $U$ (Friedman,1997) ditulis sebagai berikut:

$$
P_{B}\left(X_{1}, \ldots, X_{n}\right)=\prod_{i=1}^{n} P_{B}\left(X_{i} \mid \prod_{X_{i}}\right)=\prod_{i=1}^{n} \theta_{\left(X_{i} \mid \Pi X_{i}\right)}
$$

dengan parameter network $(\Theta)$ berisi parameter $\theta_{x_{i} \mid \Pi_{i j}}=P_{B}\left(x_{i} \mid \Pi_{x i}\right)$ untuk setiap nilai $x_{i} \in X_{i}$ dan $\prod_{x i} \in \prod_{X_{i}}$, dan $\prod_{X_{i}}$ merupakan parent dari $X_{i}$ didalam $G$.

\section{Membangun Model Tree- Augmented Network}

Membangun model TAN (Amy, 2005) (Friedman, 1997) (Murphy,2001) dilakukan berdasarkan prosedur Chow dan Liu yang mempunyai lima tahap, sebagai berikut:

1. Menghitung besarnya dependensi diantara setiap pasangan atribut yaitu $X_{i}$ dan $X_{j}, i \neq j$.

2. Membangun graph komplit tak berarah dengan node-nya merupakan atribut $X_{1}, \ldots, X_{n}$. Sedangkan bobot pada edge $X_{i} X_{j}$ adalah besarnya dependensi antara $X_{i}$ dan $X_{j}$.

3. Membangun maximum weighted spanning tree (MWST) dengan algoritma Prim's (Levitin,2003).

4. Membangun sebuah tree berarah sebagai hasil transformasi dari tree (graph) tak berarah menjadi sebuah tree berarah dengan memilih sebuah root variabel dan mensetting arah edge dari root variabel tersebut.

5. Membangun model TAN, dengan menambah simpul (vertex) yang diberi label $C$ dan menambah edge atau arc dari $C$ ke setiap $X_{i}$. 


\section{Estimasi Parameter Model TAN}

Dengan memperhatikan pada bab-bab sebelumnya maka nilai parameter $\Theta$ dari model TAN dapat ditentukan dengan menggunakan persamaan 4 (Friedman, 1997) (Jesus, 1999)

$$
\theta_{x_{i}\left|\Pi_{x_{i}}\right| C}=\hat{P}_{D}\left(x_{i}\left|\Pi_{x_{i}}\right| C\right)=\frac{\hat{P}_{D}\left(x_{i}, \prod_{x_{i}} \mid C\right)}{\hat{P}_{D}\left(\prod_{x_{i}} \mid C\right)}
$$

dengan $\hat{P}_{D}\left(x_{i}, \Pi_{x_{i}} \mid C\right) \approx N\left(\mu_{X_{j} \Pi_{x_{1}} \mid C}, \Sigma_{X_{J} \Pi_{X_{1}} \mid C}\right)$ dan $\hat{P}_{D}\left(\Pi_{x_{i}} \mid C\right) \approx N\left(\mu_{\Pi_{x_{1}} \mid C}, \Sigma_{\Pi_{X_{\perp}} \mid C}\right) \quad$ (irwan, 2012). sedangkan untuk mendapat parameter dari setiap distribusi normal (gaussian) dengan menggunakan estimator Maximum Likelihood.

\section{METODE PENELITIAN}

\subsection{Membangun Model TAN dengan Korelasi Pearson}

Langkah-langkah membangun Model TAN dengan Korelasi Pearson untuk pengenalan karakter tulisan tangan dalam bentuk image) dapat dilihat secara detail dapat Algoritma Membangun Model TAN dengan Korelasi Pearson (Irwan,2012).

\section{Algoritma Membangun Model TAN} dengan Korelasi Pearson

$$
\begin{aligned}
& \text { Model }-T A N(D) \\
& \text { for setiap } X_{i}, X_{j} \text { do } \\
& \text { Tentukan } w_{i j} \text { (bobot) } \\
& \left\{w_{i j}=\rho\left(X_{i}, X_{j}\right)=\frac{\sigma_{i j}}{\sqrt{\sigma_{i}^{2} \sigma_{j}^{2}}}\right\} \\
& G T B \leftarrow G r a p h T a k B e r a r a h(w) \\
& B N \leftarrow \text { MWST }(\text { GTB }) \\
& \{\text { maximum weighted spanning tree }\} \\
& \text { TreeB } \leftarrow \text { GraphBerarah }(B N, \text { root }) \\
& \text { TAN } \leftarrow \text { TambahC }(\text { TreeB }) \\
& \text { return TAN }
\end{aligned}
$$

Dari algoritma tersebut, Korelasi Pearson digunakan untuk menentukan bobot untuk membentuk GTB yaitu graph tak berarah dimana bobot tersebut adalah bobot dari edge sutau graph. Dengan menggunakan maximum weighted spanning tree selanjutnya dibentuk $B N$ yaitu bayesian network. Dan dengan $B N$ dan root yang dipilih, dapat dibangun TreeB yang merupakan tree berarah dan dari TreeB selanjutnya dibangun model TAN.

\subsection{Data Eksperimen}

Untuk membangun model TAN dengan mengaplikasi Korelasi Pearson digunakan data nyata dalam bentuk image karakter tulisan tangan yang terdiri dari 5 kelas (karakter) yaitu a/A , b/B, c/C, d/D dan e/E (Irwan, 2012) seperti pada Gambar 1. yang masing-masing kelas memiliki sampel berukuran 10 pengamatan tanpa membedakan huruf besar atau kecil.

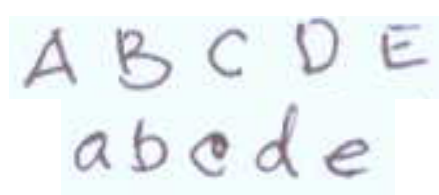

Gambar 1. Data nyata dengan lima jenis Objek karakter tulisan tangan (Irwan,2012)

Selanjutnya data nyata tersebut sebagai data training untuk membentuk model TAN. Untuk dimensi fitur objek setiap data training dibuat sama misalnya lima jenis objek karakter tulisan tangan ( $\mathrm{a} / \mathrm{A}, \mathrm{b} / \mathrm{B}$, $\mathrm{c} / \mathrm{C}, \mathrm{d} / \mathrm{D}$ dan $\mathrm{e} / \mathrm{E}$ ) dalam bentuk image dengan setiap objek ukuran dimensi atau fiturnya sama. Sebagai misal percobaan dengan dimensi objek 10x3 (30 fitur), maka dimensi image untuk lima jenis objek yang lain juga dibuat sama dengan ukuran 10x3 (30 fitur).

\subsection{Pelaksanaan Eksperimen}

Pelaksanaan eksperimen dalam penelitian ini, dengan menggunakan data nyata yaitu lima jenis karakter tulisan tangan dalam bentuk image atau citra dilaksanakan dalam beberapa tahap. Adapun langkah-langkah pelaksanaan eksperimen adalah sebagai berikut:

1. Menentukan dimensi fitur objek percobaan yaitu banyaknya fitur 
objek yang diekstraksi dari objek (image) data training.

2. Melakukan ekstraksi fitur objek berdasarkan dimensi fitur yang dipilih

3. Membangun Model TAN dengan mengaplikasikan Korelasi Pearson berdasarkan algoritma Membangun Model TAN dengan Korelasi Pearson pada sub-bab 6.1

4. Estimasi parameter model dengan mengguanakan persamaan 4 .

5. Pengenalan objek data training berdasarkan model yang telah dibangun.

6. Menghitung akurasi sistem dalam mengenali karakter tulisan tangan.

Pada langkah kedua yaitu ekstraksi fitur dari objek training dilakukan setalah objek atau image dirubah dalam bentuk grayscale disesuaikan ukuran image-nya berdasarkan dimensi fitur objek yang dipilih. Sedangkan pada langkah 5, proses pengenalan objek data training dilakukan setelah proses membangun model TAN dan estimasi parameter modelnya selesai dilakukan. Proses ini dilakukan dalam rangka untuk menghitung tingkat akurasi sistem yang sekaligus menunjukkan seberapa baik performa sistem dalam mengenali karakter tulisan tangan dengan menggunakan model TAN.

\section{HASIL DAN PEMBAHASAN}

Hasil percobaan dengan menggunakan skenario data training seperti pada pemahasan sebelumya, dengan dimensi fitur $10 \times 3$ (30 fitur) diperoleh struktur model TAN seperti pada Gambar 2.

Tingkat akurasi sistem yang dihasilkan dengan menggunakan model tersebut adalah $88 \%$ dengan perincian pengenalan dapat dilihat pada Gambar 3. Matrik Confusion Hasil pengenalan Karakter Tulisan Tangan.

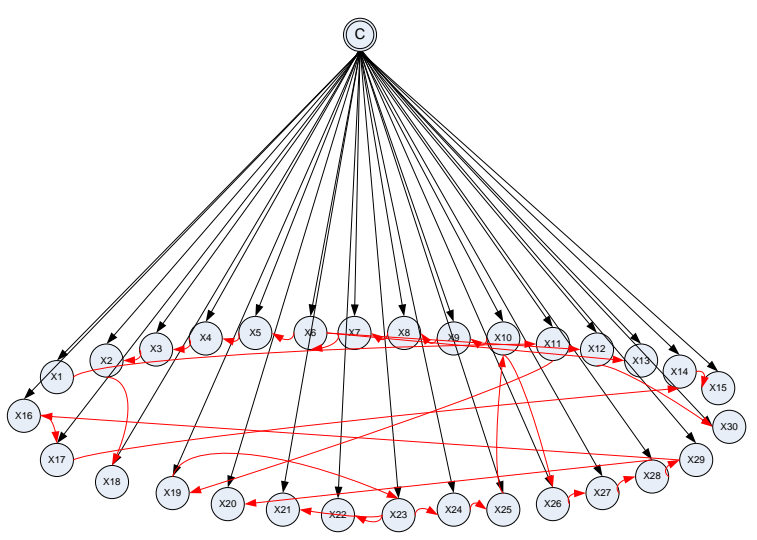
Gambar 2. Struktur Model TAN dengan dimensi objek 10x3 (30 fitur) dengan korelasi

\begin{tabular}{c|ccccc|}
\multicolumn{1}{c}{$\mathrm{a} / \mathrm{A}$} & $\mathrm{b} / \mathrm{B}$ & $\mathrm{c} / \mathrm{C}$ & $\mathrm{d} / \mathrm{D}$ & $\mathrm{e} / \mathrm{E}$ \\
$\mathrm{a} / \mathrm{A}$ & 7 & 1 & 0 & 1 & 1 \\
$\mathrm{~b} / \mathrm{B}$ & 0 & 9 & 0 & 0 & 1 \\
$\mathrm{c} / \mathrm{C}$ & 0 & 0 & 8 & 2 & 0 \\
$\mathrm{~d} / \mathrm{D}$ & 0 & 0 & 0 & 10 & 0 \\
$\mathrm{e} / \mathrm{E}$ & 0 & 0 & 0 & 0 & 10
\end{tabular}

Gambar 3. Matrik Confusion Hasil pengenalan Karakter Tulisan Tangan.

Kesalahan dalam mengenali karakter tulisan tangan ditunjukkan oleh penegenalan terhadap karakter A yaitu satu karakter yang sebenarnya karakter A dikenali sebagai karakter B, satu karakter D dan satu karakter E. Berikutnya kesalahan pada pengenalan karakter B yaitu satu karakter B dikenali sebagai karakter $\mathrm{E}$ dan kesalahan pada pengenalan karakter $\mathrm{C}$ yaitu dua karakter $\mathrm{C}$ dikenali sebagai karakter D. sedangkan untuk karakter D dan E hasil pengenlannya benar semua.

\section{KESIMPULAN}

Korelasi Pearson dapat diaplikasikan untuk membangun model pengenalan Tree-Augmented Network (TAN), yaitu untuk mengukur besarnya hubungan 
diantara pasangan fitur objek. Dari eksperimen yang dilakukan dengan menggunakan data training terdiri dari 5 jenis karakter tulisan tangan dan masingmasing fitur karakter diasumsikan mengikuti distribusi gaussian, menunjukkan untuk dimensi fitur 10x3 (30 fitur) model TAN yang dibangun dengan Korelasi Pearson mampu menghasilkan akurasi sistem sebesar $88 \%$

\section{REFERENSI}

Amy Ratnakaran, "Bayesian Network", Applied Statistics Honours,

Department of Mathematics and Statistics, University of Melbourne, 2005.

W.J. DeCoursey, "Satistics and Probability for Engineering Application With Microsoft ${ }^{\circledR}$ Excel”, Elsevier Science (USA), 2003.

Friedman, N. D. Geiger, and M. Goldszmidt, "Bayesian network classifiers", Machine Learning, vol.29, hal 131-163, 1997.

Irwan B.S, 2012, Model Pengenalan Terbaik dengan Tree-Augmented Network (TAN) dan Estimator Maximum Likelihood (ML) Berdasarkan Fitur Objek, MATICS (jurnal Ilmu Komputer dan Teknologi Informasi UIN Malang), vol.4. no.5, hal 197-203.

Jesus Cerquides, “ Applying General Bayesian Techniques to Improve TAN Induction", UBS AG Bahnhofstrasse 45, 1999.

A. Levitin, "Introduction The Design \& Analysis of Algorithms", Villanova University, 2003.

K. Murphy (2001), Bayes net matlab toolbox,www.cs.berkeley.edu/»murphy k/Bayes /bnt.html 